\title{
Role of Previous Adenovirus Infection and Its Association with IFN- $\alpha$ in Occurrence of Celiac Disease in Iraqi Patients
}

\author{
Authors \\ Hashim Raheem Tarish ${ }^{1}$, Wasan Sami Hameed ${ }^{2}$, Raad Jasim Abdul-Mehdi ${ }^{3}$, \\ Hashim Ali Abdulameer Alsherees ${ }^{4}$ \\ ${ }^{1}$ Prof. in microbiology, Head of Department of Microbiology -College of Medicine/ University of Kufa \\ ${ }^{2}$ Asist. Prof. in Immunology; Department of Microbiology -College of Medicine/University of Kufa \\ ${ }^{3}$ Med. Tech., Ph.D Stud, Department of Microbiology -College of Medicine/University of Kufa \\ ${ }^{4}$ Assist. Lecture, Department of Microbiology -College of Medicine/University of Kufa
}

\begin{abstract}
Celiac disease $(C D)$ is a chronic small intestinal immune-mediated enteropathy precipitated by exposure to dietary gluten in genetically predisposed individuals, many environmental triggering factors are suggested to participate in its pathogenesis, Several studies were struggled to establish the association between some microbial infections and CD development, some of these studies were suggested an association between adenovirus infections and CD development, but this association still un confirmed yet, so that, this study aims to evaluate the role of previous adenovirus infections and its association with IFN- $\alpha$ in occurrence of celiac disease. Sample of 80 Iraqi celiac patients has been chosen from all suspected patients who attending to Al-Suder-Medical center during the period of April 2015 to November 2015, also 80 healthy individuals (control) were included in this study, all patients were undergo blood investigations for anti-adenovirus $\operatorname{Ig} G, A G A-\operatorname{Ig} A, A G A-\operatorname{Ig} G, t T G-\operatorname{IgA}, t T G-\operatorname{Ig} G$ and IFN$\alpha$ tests. Results showed no significant difference in levels of anti-adenovirus IgG in celiac patients compared to healthy group, $p>0.05$ and there is no significant correlation between IFN- $\alpha$ and antiadenovirus IgG in celiac patients, $P>0.05$. Alsono significant correlation between anti-adenovirus IgG and AGA-IgA,P > 0.05 and no significant correlation between anti-adenovirus $\operatorname{Ig} G$ and AGA-IgG, $P>$ 0.05, andno significant correlation between anti-adenovirus $\operatorname{Ig} G$ and $t \mathrm{Tg}-\operatorname{Ig} G, P>0.05$. In other hand, there is significant correlation between anti-adenovirus $\operatorname{Ig} G$ and $\operatorname{tg} \operatorname{Ig} A, P<0.01$.

Key words: Celiac disease, adenovirus, IFN- $\alpha$, AGA, tTG-IgA.
\end{abstract}

\section{Introduction}

Celiac disease (CD) is a chronic small intestinal immune-mediated enteropathy precipitated by exposure to dietary gluten in genetically predisposed individuals ${ }^{(1)}$. A complex disorders, with environmental and genetic factors contributing to celiac disease etiology ${ }^{(2)}$. The main genetic influence on celiac disease is the HLA locus ${ }^{(3)}$, Around $90-95 \%$ of celiac patients express HLA-DQ2 heterodimer while the 
remaining $5-10 \%$ patients express the HLA-DQ8 heterodimer ${ }^{(4)}$. Infectious agents are considered as possible environmental factors that triggering autoimmune diseases, exposure to infectious agents has also been suggested as a factor causing tissue damage and inflammation, which could eventually contribute to reduced gluten tolerance in celiac disease ${ }^{(5)}$, several studies have described a possible link between celiac disease onset in susceptible patients with diverse infectious agents, and several hypotheses about the possible pathogenic mechanisms behind these associations have been discussed in present decade, including antigenic mimicry or increased immune activation secondary to infection-mediated inflammation by induction of TNF- $\alpha$, IFN- $\gamma$, INF- $\alpha$ and IL-15 ${ }^{(5)}$. One of studies proposed that CD could be triggered by the infection with adenovirus type 12 (Ad12) through mimicry of a peptide within the alpha-gliadin by the Elb protein of this (Ad12) ${ }^{(6)}$, but further studies did not sustained this hypothesis ${ }^{(7)}$. While in other study constructed on the detection of DNA coding for the E1B- $58 \mathrm{kDa}$ protein of Ad12 in biopsies of intestinal mucosa refuted the correlation between active Ad12 infection and $\mathrm{CD}$, although previous infection preceding the CD onset could not be excepted ${ }^{(8)}$. In other hand, studies constructed on the detection of the antibodies against virus in serum of $C D$ patients in compared to controls are also incongruous in confirmed the association between adenovirus infection and $\mathrm{CD}$, In a study including 44 children with CD and 60 as healthy controls, which demonstrated that children with $\mathrm{CD}$ had IgG antibody levels against E1b peptide of Ad12 significantly higher than the controls ${ }^{(9)}$. While In contrast, other study, that comprising 23 patients with $\mathrm{CD}$ and 10 control, demonstrated that no increasing in presence of specific antibodies against the E1b protein in serum of patients with CD ${ }^{(10)}$, Gabriel and his coworker were studded the presence of serum antibodies to other subtypes of IgA adenovirus (IgA-AcAd) in patients with celiac disease, in each study 80 children diagnosed with celiac disease, treated and untreated, were assayed to detect (IgA-AcAd) by ELISA technic, they concluded that there is a significant association between celiac disease and $\operatorname{IgA}-\mathrm{AcAd}(\mathrm{p}=0.002)$ can be reported in patients with treated celiac disease and there is an $\operatorname{IgA}$ AcAd activity in celiac disease in children, being in close relationship with occurrence in celiac disease regression ${ }^{(11)}$. So that, this study aims to evaluate anti-adenovirus IgG in celiac patients compared to healthy group and its association with IFN- $\alpha$ in celiac patients.

\section{Materials and Methods}

Eighty Iraqi CD patients have been chosen from all suspected patients who attending to Al-Suderteaching hospital during the period of April 2015 to November 2015 were included in this study. The age of those patients ranged from 1 year to 45 years, all patients were undergo blood sample collection to investigate anti- adenovirus $\mathrm{IgG}$, AGA-IgA, AGA-IgG, tTG-IgA , tTG-IgG and IFN- $\alpha$ tests, also 80 apparently healthy individuals from general population who had negative serological markers for celiac disease were included as control group.

Serological markers of CD (AGA-IgA, AGA-IgG, Anti-tTg-IgA and Anti-tTg-IgG) tests were done by ELIZA technic ,according to instructions of manufacture company (Aeskulisa/Germany), antiadenovirus IgG test was done by ELIZA technic, according to instructions of manufacture company (Qayeebio/ China) and IFN- $\alpha$ test was done by ELIZA technic, according to instructions of manufacture company (Elabscience/China). Statistical analysis were done by SSBS (ver. 14).

\section{Result and Discussion}

Anti-adenovirus IgG was assayed in 80 celiac patients and 80 apparently healthy individuals by ELIZA technic, Statistical parameters showed that mean of anti-adenovirus $\mathrm{IgG}$ values was $18.57 \mathrm{pg} / \mathrm{ml}$ with $\mathrm{Sd}=15.29$ for celiac patients and $18.44 \mathrm{pg} / \mathrm{ml}$ with $\mathrm{Sd}=13.42$ for healthy individuals, analysis of the difference between two groups means using (t-test), showed no 


\section{JMSCR Vol||04||Issue||04||Page 10326-10330||April}

significant decrease of anti-adenovirus $\operatorname{IgG}$ values among celiac patients compared to healthy group, $\mathrm{P}>0.05$ ( $\mathrm{p}=0.955)$, as shown in table (1).

The correlation between anti-adenovirus and any of CD serological markers(AGA-IgA, AGA-IgG, Anti-tTg-IgA and Anti-tTg-IgG) of 80 celiac patients has been obtained by using Pearson correlation test, analysis of data showed there is no significant correlation between IFN- $\alpha$ and antiadenovirus IgG in celiac patients, $\mathrm{P}>$ $0.05(\mathrm{p}=0.420)$. Also no significant correlation between anti-adenovirus IgG and AGA-IgA, P > $0.05(\mathrm{P}=0.208)$, and no significant correlation between anti-adenovirus IgG and AGA-IgG, $\mathrm{P}>$ 0.05( $\mathrm{P}=0.081)$, and no significant correlation between anti-adenovirus $\mathrm{IgG}$ and $\mathrm{tTg}-\mathrm{IgG}, \mathrm{P}>$ $0.05(\mathrm{P}=0.645)$. In other hand, there is significant correlation between anti-adenovirus IgG and $\mathrm{tTg}$ IgA, $\mathrm{P}<0.01$. As shown in table (2).

Table-1; Anti adenovirus $\operatorname{IgG}$ levels in healthy and celiac patients.

\begin{tabular}{|c|c|c|c|c|c|c|c|c|}
\hline \multirow[t]{2}{*}{ Parameters } & \multirow[t]{3}{*}{$\mathbf{N}$} & \multicolumn{3}{|c|}{ anti-Adenovirus IgG } & \multirow{3}{*}{ t- value } & \multirow{3}{*}{$\begin{array}{l}\text { P-value } \\
\text { (2-tailed) }\end{array}$} & \multirow{2}{*}{\multicolumn{2}{|c|}{$\begin{array}{lr}95 \% & \text { confidence } \\
\text { interval } & \text { o } \\
\text { difference } & \end{array}$}} \\
\hline & & \multirow{2}{*}{ Mean } & \multirow{2}{*}{$\begin{array}{l}\text { Std. } \\
\text { Deviation }\end{array}$} & \multirow{2}{*}{$\begin{array}{l}\text { Std.Error } \\
\text { Mean }\end{array}$} & & & & \\
\hline Groups & & & & & & & Lower & Upper \\
\hline Patients & 80 & $18.57 \mathrm{pg} / \mathrm{ml}$ & 15.29 & 1.71 & & & & \\
\hline Healthy & 80 & $18.44 \mathrm{pg} / \mathrm{ml}$ & 13.42 & 1.50 & & & & \\
\hline
\end{tabular}

Table (2); Correlation of anti-adenovirus IgG with CD serological markers and IFN- $\alpha$ in celiac patients.

\begin{tabular}{|c|c|c|c|c|c|c|c|}
\hline & & $\begin{array}{c}\text { Adenovirus. } \\
\lg \mathrm{G}\end{array}$ & AGA.IgA & AGA.lgG & IFN.Alpha & tTg. $\lg \mathrm{A}$ & tTg. $\lg G$ \\
\hline \multirow[t]{3}{*}{ Adenovirus.lgG } & Pearson Correlation & 1 & -.142 & -.196 & .091 & $-.421^{* *}$ & -.052 \\
\hline & Sig. (2-tailed) & & .208 & .081 & .420 & .000 & .645 \\
\hline & $\mathrm{N}$ & 80 & 80 & 80 & 80 & 80 & 80 \\
\hline \multirow[t]{3}{*}{ AGA. IgA } & Pearson Correlation & -.142 & 1 & $.573^{* *}$ & .128 & .031 & $.498^{* *}$ \\
\hline & Sig. (2-tailed) & .208 & & .000 & .256 & .785 & .000 \\
\hline & $\mathrm{N}$ & 80 & 80 & 80 & 80 & 80 & 80 \\
\hline \multirow[t]{3}{*}{ AGA.lgG } & Pearson Correlation & -.196 & $.573^{* *}$ & 1 & $-.253^{*}$ & .082 & $.659^{* *}$ \\
\hline & Sig. (2-tailed) & .081 & .000 & & .024 & .470 & .000 \\
\hline & $\mathrm{N}$ & 80 & 80 & 80 & 80 & 80 & 80 \\
\hline \multirow[t]{3}{*}{ IFN.Alpha } & Pearson Correlation & .091 & .128 & $-.253^{*}$ & 1 & .103 & .060 \\
\hline & Sig. (2-tailed) & .420 & .256 & .024 & & .364 & .598 \\
\hline & $\mathrm{N}$ & 80 & 80 & 80 & 80 & 80 & 80 \\
\hline \multirow[t]{3}{*}{ tTg. $\lg A$} & Pearson Correlation & $-.421^{\star \star}$ & .031 & .082 & .103 & 1 & .050 \\
\hline & Sig. (2-tailed) & .000 & .785 & .470 & .364 & & .659 \\
\hline & $\mathrm{N}$ & 80 & 80 & 80 & 80 & 80 & 80 \\
\hline \multirow[t]{3}{*}{ tTg. $\lg G$} & Pearson Correlation & -.052 & $.498^{* *}$ & $.659^{* *}$ & .060 & .050 & 1 \\
\hline & Sig. (2-tailed) & .645 & .000 & .000 & .598 & 659 & \\
\hline & $\mathrm{N}$ & 80 & 80 & 80 & 80 & 80 & 80 \\
\hline
\end{tabular}

${ }^{* *}$. Correlation is significant at the 0.01 level (2-tailed).

*. Correlation is signific ant at the 0.05 level (2-tailed).

The results obtained in this study ( tables; 1 and 2) were showed that no evidence of that celiac disease come from previous adenovirus infection, because no difference in anti- adenovirus $\operatorname{IgG}$ in serum of celiac patients compared to healthy, so that ,this results are in disagreement with the results of Kagnoff and his coworkers (1987), when they pointed an association between 
adenovirus and $\mathrm{CD}$ development, when they studded the role of a human intestinal adenovirus in the pathogenesis of coeliac disease and noted a region of amino acid sequence homology between A-gliadin, and the early region( E1b) protein of human adenovirus serotype 12 (Ad12), that isolated from the human intestinal tract. Also in another study, they assayed sera from celiac patients for neutralizing antibody to $\operatorname{Ad} 12$ as evidence of past exposure to that virus and for antibody to synthetic peptides of A-gliadin from the region of shared sequence with the Ad12 E1b protein and showed that $89 \%$ of untreated celiac disease patients had evidence of previous Ad12 infection, also they showed a significant increase in the prevalence of neutralizing antibody to Ad12 among treated adults (33.3\%) and children $(30.8 \%)$ with celiac disease compared with controls $(0-12.8 \%)$,so they assumed the hypothesis that a viral protein may play a role in the pathogenesis of coeliac disease ${ }^{(6)}$.

In other hand, the results of this study have agreement with the results of Mahon and his coworkers, when they studded the persistent of adenovirus infection by isolation of adenovirus type-12 DNA encoding the E1b-58 $\mathrm{kDa}$ protein from celiac patients and healthy group and find that no significant difference between the two groups ,so they suggest that persistent adenovirus type-12 infection is not a major element in the pathogenesis of celiac disease ${ }^{(8)}$.

In addition, Vesy and his coworker were studded the presence of persistent adenovirus type-12 (Ad12) infection in intestinal biopsy of $\mathrm{CD}$ patients, active peptic disease in adults and active duodenitis in children by PCR technic and showed that were not identified in significant numbers in any patients groups ,so they suggests that Ad12 virus is not involved in the persistence of these inflammatory conditions ${ }^{(12)}$.

Also, this study has agreement with study of Howdle and his coworkers, when they measured specific antibodies to the E1B-58-kDa protein in 23 celiac patients and 10 normal subjects and showed that none of the celiac sera had evidence of antibodies to the E1B-58-kDa protein and suggested that celiac patients show little evidence of humoral immunity to the specific adenovirus type-12 E1B-58-kDa ${ }^{(10)}$.

Finally, the finding of this study imply that no evidence of previous adenovirus infection associated with celiac disease development, because there is no significant difference in antiadenovirus IgG between celiac patients and healthy group and no correlation between antiadenovirus IgG and IFN- $\alpha$ in celiac patients, so this agree with the conclusion of Stepniak and Koning,(2006), when they concluding that no direct evidence supports the implication of adenovirus infections in celiac disease development ${ }^{(13)}$.

\section{Conclusions}

There is no association between previous adenovirus infection and celiac disease development.

No correlation between anti-adenovirus $\operatorname{IgG}$ and IFN- $\alpha$ in celiac patients.

\section{References}

1. Trier, J.S. (1997). Celiac Sprue and Refractory Sprue. In Sleosenger and Fordrans Gastrointestinal and Liver Disease / 6th Edition. Vol-2.

2. Rostami-Nejad M, Ishaq S, Al Dulaimi D, Zali MR, and Rostami K.( 2015).The Role of Infectious Mediators and Gut Microbiome in the Pathogenesis of Celiac Disease. Arch Iran Med ;18(4): 244 - 249.

3. Van Heel DA, Franke L, Hunt KA, Gwilliam R, Zhernakova A, Inouye M, Wapenaar MC, Barnardo MC, Bethel G, Holmes GK, Feighery C, Jewell D, Kelleher D, Kumar P, Travis S, Walters JR, Sanders DS, Howdle P, Swift J, Playford RJ, McLaren WM, Mearin ML, Mulder CJ, McManus R, McGinnis R, Cardon LR, Deloukas P, Wijmenga C.( 2007). A genome-wide association study for celiac disease identifies risk variants in 
the region harboring IL2 and IL21. Nature Genetics; 39( 7): 827-829.

4. SollidL M, Markussen G, Ek J, Gjerde H, Vartdal F, Thorsby E. (1989). Evidence for a primary association of celiac disease to a particular HLA-DQ alpha/beta heterodimer. The Journal of experimental medicine; 169: 345-350.

5. Bethune M T, Khosla C.(2008). Parallels between pathogens and gluten peptides in celiac sprue. PLoS Pathogens, vol. 4, no. 2, article e34.

6. KagnoffMF, Paterson YJ, Kumar PJ, Kasarda DD, Carbone FR, Unsworth DJ and Austin RK. (1987). Evidence for the role of a human intestinal adenovirus in the pathogenesis of coeliac disease. Gut;28 (8): 995-1001.

7. Pozo-Rubio M, Marta O, Esther N, Giada D P, Jorge R, Maria D F, Ascensi M. and Yolanda S.(2012).Immune Development and Intestinal Microbiota in Celiac Disease. Clinical and Developmental Immunology; Vol. 2012, Review Article ID 654143, 12 pages.doi:10.1155/2012/654143.

8. Mahon J, Blair G E, Wood G M, Scott B B, Losowsky $\mathrm{M}$ S, and Howdle $\mathrm{P}$ D.(1991). Is persistent adenovirus 12 infection involved in coeliac disease? A search for viral DNA using the polymerase chain reaction. Gut; 32(10):1114-1116.

9. LahdeahoM L, Lehtinen M, Rissa H R, Hyoty H, Reunala T, and Maki M.(1993). Antipeptide antibodies to adenovirus E1b protein indicate enhanced risk of celiac disease and dermatitis herpetiformis. International Archives of Allergy and Immunology; 101( 3): 272-275.

10. HowdleP D, Zajdel M E B, Smart C J, Trejdosiewicz L K, Blair G E, and Losowsky M S. (1989). Lack of a serologic response to an E1B protein of adenovirus 12 in coeliac disease. Scandinavian Journal of Gastroenterology; 24(3):282-286.

11. Gabriel S, Alexandru P, Nicolae $M$, Mariana A, Victor C, and Doru D.(2011).ADENOVIRUSURI ÎN BOALA CELIACĂ LA COPIL.Romanian Journal of Infectious Diseases ; 14 (1): 5-9.

12. VesyCJ, Greenson JK, Papp AC, Snyder PJ, Qualman SJ, and Prior TW.(1993).Evaluation of celiac disease biopsies for adenovirus 12 DNA using a multiplex polymerase chain reaction. $M o d$ Pathol;6(1):61-64.

13. StepniakD, Koning F. (2006).General introduction: Celiac disease - sandwiched between innate and adaptive immunity.Hum Immunol ;67(6):460-8. 